\title{
PENGARUH INTELEKTUAL CAPITAL TERHADAP PROFITABILITAS PADA PERUSAHAAN INDUSTRI JASA SEKTOR PROPERTI DAN REAL ESTATE DI BURSA EFEK INDONESIA TAHUN 2011 - 2015
}

\author{
LISTIYA IKE PURNOMO \\ Universitas Pamulang \\ listiyaike81@gmail.com
}

\begin{abstract}
This study aims to determine whether Intellectual Capital is proxyed with Value Added Intellectual Coeffisien significant effect on profitability measured by ROA using Data Panel analysis method that is processed with Eviews 7.0 program. Value Added Capital Employed (VACA) denotes t-statistic > t-table of 0.610972 $<1.97253$, and its probability value of $0.5420>0.05$ proves no significant effect of Value Added Capital Employed (VACA) on Return On Assets (ROA). Value Added Human Capital (VAHU) shows t-statistic > t-table that is 5.324171> 1.97253 , and the probability value of $0.0000<0.05$ membahikkan there is a significant influence of Value Added Human Capital (VAHU) on Return On Assets (ROA). Structural Capital Value Added (STVA) shows t-statistic > t-table is $2.559279>1.97253$, and the probability value of $0.0113<0.05$ proves that there is a significant influence of Structural Capital Value Added (STVA) to Return On Assets (ROA). Value Added Intellectual Coefficients (VAIC) shows t-statistic > ttable that is $20.21010>1.97253$, and the probability value of $0.0000<0.05$ proves there is a significant influence of Value Added Intellectual Coefficient (VAIC) to Return On Assets (ROA). Simultaneous test results show F-statistic > F-table is $59.13104>2.42$ and the probability value of $0.000000<0.05$ membuktikkan together elements of Intellectual Capital have a significant effect on Return On Assets (ROA). Adjusted R-Squared (R2) of 0.558249 indicates that the percentage of contribution of independent variable to dependent variable is $55,8 \%$. Based on the results of testing and discussion, it can be concluded that Intellectual Capital (IC) as measured by Value Added Capital Employed (VACA), Value Added Human Capital (VAHU), Structural Capital Value Added (STVA) and Value Added Intellectual Capital (VAIC) Have a significant effect on profitability as measured by Return On Assets (ROA).
\end{abstract}

Keyword: Intellectual Capital, Profitabilitas

\begin{abstract}
Abstrak
Penelitian ini bertujuan untuk mengetahui apakah Intellectual Capital diproksikan dengan Value Added Intellectual Coeffisien berpengaruh signifikan terhadap
\end{abstract}


profitabilitas yang diukur dengan ROA menggunakan metode analisis Data Panel yang diolah dengan program Eviews 7.0. Value Added Capital Employed (VACA) menunjukkan t-statistik $>$ t-tabel $0,610972<1,97253$, dan nilai probabilitasnya $0,5420>0,05$ membuktikan tidak ada pengaruh signifikan dari Value Added Capital Employed (VACA) pada Return On Assets (ROA). Nilai Tambah Modal Manusia (VAHU) menunjukkan t-statistik> t-tabel yaitu 5,324171> 1,97253, dan nilai probabilitas $0,0000<0,05$ membuktikan terdapat pengaruh signifikan Value Added Human Capital (VAHU) terhadap Return On Assets (ROA). Structural Capital Value Added (STVA) menunjukkan t-statistik> ttabel adalah 2,559279> 1,97253, dan nilai probabilitas $0,0113<0,05$ membuktikan bahwa ada pengaruh signifikan dari Structural Capital Value Added (STVA) terhadap Return On Assets (ROA) . Nilai Tambah Intelektual Koefisien (VAIC) menunjukkan t-statistik> t-tabel yaitu 20,21010> 1,97253, dan nilai probabilitas 0,0000 $<0,05$ membuktikan ada pengaruh signifikan Value Added Intellectual Coefficient (VAIC) terhadap Return On Assets (ROA) . Hasil uji simultan menunjukkan F-statistic> F-tabel adalah 59,13104> 2,42 dan nilai probabilitas 0,000000 $<0,05$ membuktikkan bersama-sama elemen Intellectual Capital memiliki pengaruh yang signifikan terhadap Return On Assets (ROA). Adjusted R-Squared (R2) sebesar 0,558249 menunjukkan bahwa persentase kontribusi variabel independen terhadap variabel dependen adalah 55,8\%. Berdasarkan hasil pengujian dan pembahasan, dapat disimpulkan bahwa Intellectual Capital (IC) yang diukur dengan Value Added Capital Employed (VACA), Value Added Human Capital (VAHU), Structural Capital Value Added (STVA) dan Value Added Intellectual Capital (VAIC) Memiliki pengaruh yang signifikan terhadap profitabilitas yang diukur dengan Return On Assets (ROA).

Kata Kunci: Modal Intelektual, Profitabilitas

\section{PENDAHULUAN}

Era perdagangan bebas telah melahirkan blok-blok perdagangan baik tingkat regional maupun global. Seperti saat ini, dimana kita harus siap menghadapi MEA (Masyarakat Economy Asia). Implementasi MEA tersebut akan mendorong liberalisasi arus barang, jasa, investasi dan tenaga kerja terampil antar negara anggota. Oleh karena itu, setiap perusahaan harus memiliki keunggulan kompetitif (competitive advantage) untuk memenangkan persaingan di masa yang akan datang. Globalisasi, inovasi teknologi dan persaingan yang ketat pada abad ini memaksa perusahaan-perusahaan mengubah cara mereka menjalankan bisnisnya. Agar dapat terus bertahan dengan cepat perusahaanperusahaan mengubah dari bisnis yang didasarkan pada tenaga kerja (labor-based business) menuju bisnis berdasarkan pengetahuan (knowledge based business), dengan karakteristik utama ilmu pengetahuan. Seiring dengan perubahan ekonomi yang memiliki karakteristik ekonomi berbasis ilmu pengetahuan dengan penerapan manajemen pengetahuan (knowledge management) maka kemakmuran 
suatu perusahaan akan bergantung pada suatu penciptaan transformasi dari ilmu pengetahuan itu sendiri.

Dalam meningkatkan kinerja suatu perusahaan dapat dilakukan penilaian dan pengukuran, tidak hanya pada aset berwujud tetapi juga pada aset tak berwujud. Salah satu pendekatan yang digunakan dalam penilaian dan pengukuran aset tak berwujud tersebut adalah Intellectual Capital (IC) yang telah menjadi fokus perhatian dalam berbagai bidang, baik manajemen, teknologi informasi, sosiologi, maupun akuntansi. Aset tidak berwujud khususnya Intellectual Capital (IC), mengacu pada pengetahuan dan kemampuan mengetahui dari sebuah kolektifitas organisasi yang meliputi pengetahuan, ketrampilan dan kapabilitas yang memungkinkan seseorang bertindak dengan cara baru. Intellectual Capital (IC) dapat didefinisikan sebagai ilmu pengetahuan atau daya pikir yang dimiliki oleh karyawan pada suatu perusahaan yang tidak berwujud sehingga dapat memberikan nilai tambah pada perusahaan. Intellectual Capital (IC) merupakan faktor penentu keberhasilan perusahaan di persaingan global.

Di Indonesia masih belum terdapat peraturan yang mengatur tentang pengakuan, pengukuran dan pengungkapan Intellectual Capital (IC). Di Indonesia, fenomena Intellectual Capital (IC) mulai berkembang terutama setelah munculnya PSAK No. 19 (revisi 2010) tentang aktiva tidak berwujud. PSAK No. 19 (revisi 2010) mulai berlaku 1 Januari 2011 menggantikan PSAK No.19 (Revisi 2000): Aset Tidak Berwujud. PSAK ini menentukan perlakuan akuntansi aset tak berwujud yang tidak diatur secara khusus pada PSAK lainnya. Pernyataan ini mengatur tata cara pengakuan, pengukuran dan pengungkapan aset tidak berwujud. Meskipun tidak dinyatakan secara eksplisit sebagai Intellectual Capital (IC), namun lebih kurang Intellectual Capital (IC) telah mendapat perhatian. Menurut PSAK No. 19, aktiva tidak berwujud adalah aktiva nonmoneter yang dapat diidentifikasi dan tidak mempunyai wujud fisik serta dimiliki untuk digunakan dalam menghasilkan atau menyerahkan barang atau jasa, disewakan kepada pihak lainnya, atau untuk tujuan administratif.

Meningkatnya pengakuan Intellectual Capital (IC) dalam mendorong nilai dan keunggulan kompetitif perusahaan, pengukuran yang tepat terhadap Intellectual Capital (IC) perusahaan belum dapat ditetapkan. Misalnya, Pulic (2000) dalam Ulum (2007) tidak mengukur secara langsung Intellectual Capital (IC) perusahaan, tetapi mengajukan suatu ukuran untuk menilai efisiensi dari nilai tambah sebagai hasil dari kemampuan intelektual perusahaan (Value Added Intellectual Coefficient - VAIC ${ }^{\mathrm{TM}}$ ). Komponen utama dari VAIC ${ }^{\mathrm{TM}}$ dapat dilihat dari sumber daya perusahaan, yaitu physical capital (VACA - value added capital employed), human capital (VAHU - value added human capital), dan structural capital (STVA - structural capital value added). Meskipun demikian, metode Pulic memiliki keuanggulan yaitu kemudahan dalam perolehan data yang digunakan dalam penelitian. Data yang dibutuhkan untuk menghitung berbagai rasio tersebut adalah angka-angka keuangan standar yang terdapat dalam laporan keuangan perusahaan.

Kesulitan mengukur aset tidak berwujud dipandang sebagai suatu masalah karena menyebabkan manajemen tidak dapat efisien dalam mengelola intangible aset. 
Hal tersebut terjadi karena adanya keterbatasan informasi yang menunjukan keberadaan intangible aset, sehingga laporan yang disajikan oleh perusahaan terkadang dinilai kurang relevan. Pulic (2000) mengungkapkan masalah yang mendasari keterbatasan pengukuran Intellectual capital, yaitu :

1) Intellectual capital masih tidak dianggap sebagai suatu sumber daya yang sederajat dengan modal fisik dan financial perusahaan.

2) Adanya ketidaksesuaian antara model pengukuran terbaru dan sistem akuntansi yang berlaku.

Penelitian ini berusaha meneliti pengaruh intellectual capital terhadap profitabilitas perusahaan industri jasa sektor properti dan real estate yang tercatat di Bursa Efek Indonesia (BEI) periode tahun 2011 hingga 2014. Pemilihan industri jasa sektor properti dan real estate sebagai sampel mengacu pada penelitian Firer \& Stainbank (2003) dalam Suhendah (2012), yang mengungkapkan bahwa 4 dari 6 kategori yang masuk ke dalam industri high knowledge-based didominasi oleh perusahaan-perusahaan yang bergerak di industri jasa, sehingga penggunaan intellectual capital dalam bisnisnya lebih intensif dibanding perusahaan lainnya.

Pengambilan populasi perusahaan industri jasa sektor properti dan real estate juga didasarkan pemikiran bahwa perusahaan pada kelompok ini termasuk perusahaan yang memiliki karakteristik perusahaan padat intellectual capital (high IC-intensive industries). Industri jasa sektor properti dan real estate adalah perusahaan yang berkembang pesat dan mendukung perekonomian di Indonesia. Ditinjau dari segi keberlanjutan usaha, sektor tersebut memiliki sumber daya yang baik, terlihat pada desain-desain properti dengan arsitektur yang modern, kemampuan memasarkan produk dengan harga yang bersaing, dan tenaga perancang desain yang mumpuni. Keberlanjutan usaha pada sektor tersebut, tentunya didukung dari studi kelayakan bisnis pada sektor properti dan real estate. Hal-hal tersebut menjadi indikator penting bagi perusahaan dalam mengelola sumber daya yang berkaitan erat dengan intellectual capital. Berdasarkan pertimbangan tersebut maka peneliti memilih perusahaan sektor properti dan real estate.

Berdasarkan latar belakang tersebut, maka penulis dapat menentukan perumusan masalah sebagai berikut:

1. Bagaimana pengaruh Value Added Capital Employed (VACA) terhadap profitabilitas yang diukur dengan Return On Asset (ROA) pada perusahaan industri jasa sektor properti dan real estate?

2. Bagaimana pengaruh Value Added Human Capital (VAHU) terhadap profitabilitas yang diukur dengan Return On Asset (ROA) pada perusahaan industri jasa sektor properti dan real estate?

3. Bagaimana pengaruh Structural Capital Value Added (STVA) terhadap profitabilitas yang diukur dengan Return On Asset (ROA) pada perusahaan industri jasa sektor properti dan real estate?

4. Bagaimana pengaruh Value Added Intelectual Coeficient (VAIC) terhadap profitabilitas yang diukur dengan Return On Asset (ROA) pada perusahaan industri jasa sektor properti dan real estate? 
5. Bagaimana pengaruh Value Added Capital Employed (VACA), Value Added Human Capital (VAHU), Structural Capital Value Added (STVA), dan Value Added Intelectual Coeficient (VAIC) secara bersama-sama terhadap profitabilitas yang diukur dengan Return On Asset (ROA) pada perusahaan industri jasa sektor properti dan real estate?

Berdasarkan perumusan masalah di atas, maka tujuan penelitian ini yaitu untuk mengetahui dan memberikan bukti empiris: pengaruh Intellectual Capital (IC) yang diproksikan dengan Value Added Intellectual Coefficientl (VAIC) terhadap profitabilitas yang diukur dengan Return On Asset (ROA) pada perusahaan industri jasa sektor properti dan real estate.

\section{TINJAUAN PUSTAKA}

\subsection{Manajemen}

Manajemen adalah ilmu (sekumpulan pengetahuan yang sistematis, telah dikumpulkan dan di terima secara umum dengan suatu objek atau objek tertentu) dan seni (suatu kreativitas, pribadi yang kuat dan disertai keterampilan) mengatur, memanfaatkan SDM dan sumber daya lainnya secara efektif dan efisien untuk mencapai suatu tujuan tertentu. SP. Hasibuan (2008:50).

\subsection{Manajemen Keuangan}

Menurut Eugene F. Brigham dan Joel F. Houston (2010:4) yang di alih bahasakan oleh Ali Akbar Yulianto mengenai definisi dari manajemen keuangan, mereka mengemukakan bahwa: "Manajemen keuangan dapat diterangkan berdasarkan fungsi dan tanggung jawab dari manajer keuangan. Fungsi utama manajer keuangan adalah merencanakan, mencari dan memanfaatkan dana dengah berbagai cara untuk memaksimumkan efisiensi (daya guna) dari operasi-operasi perusahaan".

\subsection{Teori Stakeholder}

Teori yang mendasari penelitian ini adalah stakeholder theory. Teori stakeholder lebih mempertimbangkan posisi para stakeholder yang dianggap powerfull. Kelompok stakeholder inilah yang menjadi pertimbangan utama bagi perusahaan dalam mengungkapkan dan/atau tidak mengungkapkan suatu informasi di dalam laporan keuangan. Dalam pandangan teori stakeholder, perusahaan memiliki stakeholders, bukan sekedar shareholder (Riahi-Belkaoui, 2003 dalam Rousulita Suhendah, 2012). Kelompok kelompok 'stake' tersebut, menurut Riahi-Belkaoui, meliputi pemegang saham, karyawan, pelanggan, pemasok, kreditor, pemerintah, dan masyarakat.

Konsensus yang berkembang dalam konteks teori stakeholder adalah bahwa laba akuntansi hanyalah merupakan ukuran return bagi pemegang saham (shareholder), sementara value added adalah ukuran yang lebih akurat yang diciptakan oleh stakeholders dan kemudian didistribusikan kepada stakeholders yang sama (Meek dan Gray, 1988 dalam Ulum, 2009). Value Added yang dianggap memiliki akurasi lebih tinggi dihubungkan dengan return yang dianggap 
sebagai ukuran bagi shareholder. Sehingga dengan demikian keduanya (value added dan return) dapat menjelaskan kekuatan teori stakeholder dalam kaitannya dengan pengukuran kinerja organisasi.

\subsection{Teori Resource-Based}

Sumber daya yang dimiliki perusahaan bersifat heterogen, tidak homogen dan memiliki karakteristik khusus dan unik di setiap perusahaan (Penrose, 1959 dalam Pratiwi, 2005). Perusahaan yang membangun sumber dayanya sendiri dan dapat mengendalikannya akan mempunyai kemampuan mempertahankan keunggulannya dibandingkan jika perusahaan membeli atau memperoleh sumber dayanya dari luar organisasi. Kumpulan sumber daya yang unik yang dimiliki dan dikendalikan perusahaan memungkinkan perusahaan untuk mencapai dan mempertahankan kinerja superior yang berkelanjutan.

Sumber daya unik yang dimaksudkan dalam teori Resource-Based adalah sumber daya yang mempunyai sifat bermanfaat/bernilai (valuable), langka (rare), tidak dapat ditiru (inimitable), dan tidak terganti (non-subtitutable). Bernilai artinya dapat digunakan untuk aktivitas perusahaan, langka berarti hanya dimiliki oleh sedikit perusahaan saja. Tidak dapat ditiru berarti sumber daya tersebut dilindungi dari kemungkinan ditiru oleh pesaing. Tidak terganti artinya sumber daya hanya dimiliki oleh per-usahaan tertentu saja dan tidak dapat diganti dengan produk lain (Barney, et al. 2001 dalam Widyaningdyah, 2013). Jenis sumber daya ini dapat mengantarkan perusahaan pada pencapaian keunggulan kompetitif.

\subsection{Intellectual Capital (IC)}

Perhatian perusahaan terhadap pengelolaan Intellectual Capital (IC) beberapa tahun terakhir ini semakin meningkat. Hal ini disebabkan adanya kesadaran bahwa Intellecrual Capital merupakan landasan bagi perusahaan tersebut untuk berkembang dan mempunyai keunggulan dibandingkan perusahaan lain. Ada banyak definisi berbeda mengenai Intellectual Capital.

Intellectual Capital adalah informasi dan pengetahuan yang diaplikasikan dalam pekerjaan untuk menciptakan nilai (Purnomosidhi, 2012).

Intellectual Capital dapat dipandang sebagai pengetahuan, dalam pembentukan kekayaan intelektual dan pengalaman yang dapat digunakan untuk menciptakan kekayaan (Wahdikorin, 2010).

\subsection{Elemen-elemen Intellectual Capital.}

Beberapa para ahli telah mengemukakan elemen-elemen apa saja yang terdapat dalam intellectual capital. Namun dari semuanya, tidak ada ketetapan pasti mengenai elemen-elemen dalam Intellectual Capital. Sehingga secara umum, elemen-elemen dalam modal intelektual terdiri dari Human Capital (HC), Structural Capital (SC), dan Customer Capital (CC) (Bontis et all.; 2004).

Definisi dari masing-masing komponen Intellectual Capital Menurut Bontis (2004), yaitu:

1) Human capital adalah kombinasi dari pengetahuan, skill, kemampuan melakukan inovasi dan kemampuan menyelesaikan tugas, meliputi nilai perusahaan, kultur dan filsafatnya. Jika perusahaan berhasil dalam mengelola 
pengetahuan karyawannya, maka hal itu dapat meningkatkan human capital. Sehingga human capital merupakan kekayaan yang dimiliki oleh suatu perusahaan yang terdapat dalam tiap individu yang ada di dalamnya. Human capital ini yang nantinya akan mendukung structural capital dan customer capital.

2) Structural Capital (SC) adalah infrastruktur yang dimiliki oleh suatu perusahaan dalam memenuhi kebutuhan pasar. Termasuk dalam structural capital yaitu sistem teknologi, sistem operasional perusahaan, paten, merk dagang dan kursus pelatihan.

3) Customer Capital (CC) adalah orang-orang yang berhubungan dengan perusahaan, yang menerima pelayanan yang diberikan oleh perusahaan tersebut

\subsection{Value Added Intellectual Coefficient (VAIC)}

(Pulic, 2000 dalam Suhendah, 2012) mengusulkan Koefisien Nilai Tambah Intelektual atau Value Added Intellectual Coefficient (VAIC) untuk menyediakan informasi tentang efisiensi penciptaan nilai dari aset berwujud dan tidak berwujud dalam perusahaan. Value Added Intellectual Coefficient (VAIC) digunakan karena dianggap sebagai indikator yang cocok untuk mengukur Intelellctual Capital di riset empiris.

Beberapa alasan utama yang mendukung penggunaan Value Added Intellectual Coefficient (VAIC ${ }^{\mathrm{TM}}$ ) diantaranya yaitu: Yang pertama, VAIC ${ }^{\mathrm{TM}}$ menyediakan dasar ukuran yang standar dan konsisten, angka-angka keuangan yang standar yang umumnya tersedia dari laporan keuangan perusahaan (Pulic, 2000 dalam Suhendah, 2012), sehingga memungkinkan lebih efektif melakukan analisis komparatif internasional menggunakan ukuran sampel yang besar di berbagai sektor industri. Kedua, semua data yang digunakan dalam perhitungan Value Added Intellectual Coefficient (VAIC) didasarkan pada informasi yang telah diaudit, sehingga perhitungan dapat dianggap objektif dan dapat diverifikasi (Pulic, 2000 dalam Suhendah, 2012).

Value Added Intellectual Coefficient (VAIC) adalah sebuah prosedur analitis yang dirancang untuk memungkinkan manajemen, pemegang saham dan pemangku kepentingan lain yang terkait untuk secara efektif memonitor dan mengevaluasi efisiensi nilai tambah atau Value Added (VA) dengan total sumber daya perusahaan dan masing masing komponen sumber daya utama. Value added (VA) adalah perbedaan antara pendapatan (OUTPUT) dan beban (INPUT).

Metode VAIC mengukur efisiensi tiga jenis input perusahaan yaitu modal manusia, modal struktural, serta modal fisik dan finansial yang terdiri dari:

1) Value Added Human Capital (VAHU) adalah indikator efisiensi nilai tambah modal manusia. VAHU merupakan rasio dari Value Added (VA) terhadap Human Capital (HC). Hubungan ini mengindikasikan kemampuan modal manusia membuat nilai pada sebuah perusahaan. VAHU dapat diartikan juga sebagai kemampuan perusahaan menghasilkan nilai tambah setiap rupiah yang dikeluarkan pada modal manusia. VAHU menunjukkan berapa banyak Value Added (VA) dapat dihasilkan dengan dana yang dikeluarkan untuk tenaga kerja (Ulum, 2008). 
2) Structural Capital Value Added (STVA) adalah indikator efisiensi nilai tambah modal struktural. STVA merupakan rasio dari Structural Capital (SC) terhadap Value Added (VA). Rasio ini mengukur jumlah SC yang dibutuhkan untuk menghasilkan 1 rupiah dari VA dan merupakan indikasi bagaimana keberhasilan SC dalam penciptaan nilai (Tan et all, 2007).

3) Valur Added Capital Employed (VACA) adalah indikator efisiensi nilai tambah modal yang digunakan. VACA merupakan rasio dari Value Added (VA) terhadap Capital Employed (CE). VACA menggambarkan berapa banyak nilai tambah perusahaan yang dihasilkan dari modal yang digunakan. VACA yaitu kalkulasi dari kemampuan mengelola modal perusahaan (Imaningati, 2007)

\subsection{Profitabilitas}

Profitabilitas adalah kemampuan perusahaan untuk menghasilkan laba dalam kegiatan operasi yang merupakan fokus utama dalam penilaian prestasi perusahaan. Laba menjadi indikator kemampuan perusahaan dalam memenuhi kewajiban kepada kreditur dan investor, serta merupakan bagian dalam proses penciptaan nilai perusahaan berkaitan dengan prospek perusahaan di masa depan.

Rasio profitabilitas perusahaan adalah rasio yang diukur berdasarkan perbandingan antara laba setelah pajak dengan total aktiva perusahaan. Profitabilitas merupakan ukuran penting untuk menilai perusahaan yang mempengaruhi investor untuk membuat keputusan. Salah satu rasio profitabilitas adalah Return on Asset (ROA).

Menurut Brigham dan Houston yang dialih bahasakan oleh Ali Akbar Yulianto (2010:148), "Rasio laba bersih terhadap total aktiva mengukur pengembalian atas total aktiva setelah bunga dan pajak". Return on Asset (ROA) merefleksikan keuntungan bisnis dan efisiensi perusahaan dalam pemanfaatan total assets Chen et al., 2005 dalam Ulum (2007).

\subsection{Pengembangan Hipotesis}

Sugiyono (2008 : 93) menyatakan bahwa hipotesis adalah jawaban sementara terhadap rumusan masalah dalam penelitian. Dikatakan sementara karena jawaban yang diberikan baru didasarkan pada teori-teori relevan. Belum didasarkan fakta empiris yang diperoleh melalu pengumpulan data.

Berdasarkan kaJIAn teori berbasis sumber daya, sebuah perusahaan diibaratkan sebagai kumpulan dari aset maupun kemampuan berwujud dan tak berwujud (Firer and Williams, 2003 dalam Rohman 2013). Teori ini menyarankan bahwa kinerja dari sebuah perusahaan sebaiknya didefinisikan sebagai fungsi penggunaan yang efektif dan efisien dari aset berwujud maupun tak berwujud yang dimiliki oleh perusahaan. Sehingga hal ini sesuai dengan teori stakeholder yang menyatakan bahwa value added merupakan instrument pengukuran yang lebih akurat dalam mengukur kinerja sebuah perusahaan dibandingkan dengan laba akuntansi yang hanya merupakan ukuran return bagi pemegang saham.

Apabila dengan intellectual capital dapat meminimalkan pengeluaran sehingga aset yang dimiliki dapat digunakan secara lebih efisien, maka akan dapat dihasilkan keuntungan bagi perusahaan sehingga meningkatkan angka 
profitabilitas ROA. Ulum et al. (2007) meneliti pengaruh IC dengan kinerja keuangan yang diproksikan dengan ROA dan diperoleh hasil dari keduanya bahwa IC berpengaruh positif terhadap profitabilitas perusahaan (ROA).

Dengan menggunakan VAICTM yang diformulasikan oleh Pulic (1998; 1999; 2000) sebagai ukuran kemampuan intelektual perusahaan (corporate intellectual ability), diajukan hipotesis penelitian ini sebagai berikut:

H1 : Di duga Value Added Capital Employed (VACA) berpengaruh signifikan terhadap profitabilitas yang diukur dengan Return On Asset (ROA) pada perusahaan industri jasa sektor properti dan real estate di Indonesia.

H2 : Di duga Value Added Human Capital (VAHU) berpengaruh signifikan terhadap profitabilitas yang diukur dengan Return On Asset (ROA) pada perusahaan industri jasa sektor properti dan real estate di Indonesia.

H3 : Di duga Structural Capital Value Added (STVA) berpengaruh signifikan terhadap profitabilitas yang diukur dengan Return On Asset (ROA) pada perusahaan industri jasa sektor properti dan real estate di Indonesia.

H4 : Di duga Value Added Intelectual Coefisien (VAIC) berpengaruh signifikan terhadap profitabilitas yang diukur dengan Return On Asset (ROA) pada perusahaan industri jasa sektor properti dan real estate di Indonesia.

H5 : Di duga Value Added Capital Employed (VACA), Value Added Human Capital (VAHU), Structural Capital Value Added (STVA) dan Value Added Intelectual Coefisien (VAIC) secara bersama-sama berpengaruh signifikan terhadap kinerja perusahaan yang diukur dengan Return On Asset (ROA).

\section{METODE PENELITIAN}

\subsection{Desain Penelitian}

Desain penelitian merupakan suatu cara penulis dalam menganalisis data. Penelitian ini didesain menggunakan metode deskriptif analisis dengan pendekatan kuantitatif, yaitu hasil penelitian yang kemudian diolah dan dianalisis untuk diambil kesimpulannya, artinya penelitian yang dilakukan adalah penelitian yang menekankan analisisnya pada data-data numeric (angka) sehingga akan diketahui hubungan yang signifikan antara variabel yang diteliti, kemudian menghasilkan kesimpulan yang akan memperjelas gambaran mengenai objek yang diteliti. Desain penelitian menggambarkan adanya prosedur-prosedur yang memungkinkan penulis dapat menguji hipotesis penelitian yang telah ditulis sehingga dapat mencapai kesimpulan mengenai hubungan atau adanya saling mempengaruhi antara variabel bebas dan variabel terikat dalam penelitian ini.

Adapun desain penelitian yang ditetapkan dalam penelitian ini adalah sebagai berikut: 


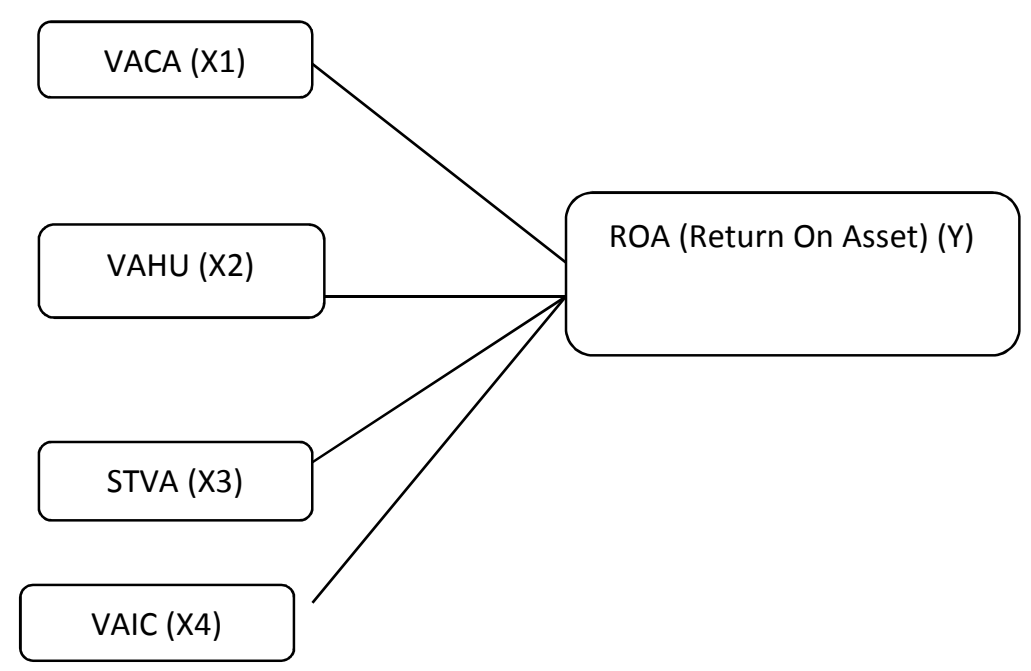

Gambar 3.1

Desain Penelitian

\subsection{Penentuan Sampel}

Populasi yang digunakan dalam penelitian ini adalah perusahaan industri jasa sektor properti dan real estate yang terdaftar di Bursa Efek Indonesia pada periode tahun 2011 hingga 2015. Sektor properti dan real estate merupakan salah satu industri jasa non keuangan yang termasuk dalam perusahaan knowledge based yaitu perusahaan yang memanfaatkan teknologi untuk mendapatkan nilai tambah dan memiliki keuanggulan bersaing.

Penentuan jumlah sampel yang akan diolah dari jumlah populasi yang banyak, memerlukan teknik sampling yang tepat. Teknik sampling merupakan teknik pengambilan sampel yang akan digunakan dalam penelitian, terdapat berbagai teknik sampling yang digunakan.

Penentuan sampel dalam penelitian ini dilakukan secara purposive sampling dengan kriteria sebagai berikut:

1. Laporan keuangan yang telah diaudit dan dipublikasikan pada tahun 20112015.

2. Bila ada ketidaktersediaan data dari salah satu variabel pada perusahaan tertentu maka emiten tersebut tidak digunakan sebagai sampel.

3. Perusahaan tersebut tidak memiliki laba yang negatif selama periode pengamatan yaitu pada tahun $2011-2015$.

Tabel 3.3. Pemilihan Sampel

\begin{tabular}{|l|c|}
\hline \multicolumn{1}{|c|}{ Keterangan } & Jumlah \\
\hline Perusahaan industri jasa sektor properti dan real estate & 60 \\
\hline
\end{tabular}




\begin{tabular}{|c|c|} 
Perusahaan yang datanya tidak lengkap & -15 \\
\hline Perusahaan yang menderita rugi pada periode pengamatan & -8 \\
\hline Jumlah Sampel & 37 \\
\hline
\end{tabular}

Sumber: www.sahamoke.com, diolah.

\subsection{Operasional Variabel}

Operasionalisasi variabel diperlukan untuk menentukan jenis, indikator, serta skala dari variabel-variabel yang terkait dalam penelitian, sehingga pengujian hipotesis dengan alat bantu statistik dapat dilakukan secara benar, maka dalam penelitian ini terdapat dua variabel yang digunakan yaitu:

\subsubsection{Variabel Independen}

Variabel Independen dalam penelitian ini adalah Intellectual Capital yang dimaksud dalam penelitian ini adalah kinerja Intellectual Capital yang diukur berdasarkan value added yang diciptakan oleh physical capital (VACA), value added human capital (VAHU), dan structural capital value added (STVA). Kombinasi dari ketiga value added tersebut disimbolkan dengan nama Value Added Intelectual Coefficient Technology Model (VAICTM) yang dikembangkan oleh Pulic (2000). Konsep ini telah diuji dan diadopsi oleh peneliti-peneliti di luar negeri Firer dan Williams (2003); Mavridis (2004); Chen et al., (2005); Kamath (2007); dan Tan et al. (2007) dalam Ulum 2007. Formulasi dan tahapan perhitungan VAICTM adalah sebagai berikut:

3.3.1.1 Tahap Pertama: Menghitung Value Added (VA).

VA dihitung sebagai selisih antara output dan input (Pulic, 1999) dalam Ulum 2007.

\section{VA = OUT - IN}

Dimana:

OUT $=$ Output $=$ total penjualan dan pendapatan lain.

IN = Input = beban penjualan dan biaya-biaya lain (selain beban karyawan).

3.3.1.2 Tahap Kedua: Menghitung Value Added Capital Employed (VACA).

VACA adalah indikator untuk VA yang diciptakan oleh satu unit dari physical capital. Rasio ini menunjukkan kontribusi yang dibuat oleh setiap unit dari CE terhadap value added organisasi.

VACA $=$ VA/CE

Dimana:

VACA = Value Added Capital Employed $=$ rasio dari VA terhadap CE.

$\mathrm{VA}=$ value added

$\mathrm{CE}=$ Capital Employed $=$ dana yang tersedia (total ekuitas)

3.3.1.3 Tahap Ketiga: Menghitung Value Added Human Capital (VAHU).

VAHU menunjukkan berapa banyak VA dapat dihasilkan dengan dana yang dikeluarkan untuk tenaga kerja. Rasio ini menunjukkan kontribusi yang dibuat oleh setiap rupiah yang diinvestasikan dalam HC terhadap value added organisasi.

VAHU $=$ VA/HC 
Dimana:

VAHU = Value Added Human Capital = rasio dari VA terhadap HC.

$\mathrm{VA}=$ value added

$\mathrm{HC}=$ Human Capital = beban karyawan.

3.3.1.4 Tahap Keempat: Menghitung Structural Capital Value Added (STVA).

Rasio ini mengukur jumlah SC yang dibutuhkan untuk menghasilkan 1 rupiah dari VA dan merupakan indikasi bagaimana keberhasilan SC dalam penciptaan nilai.

STVA $=$ SC/VA

Dimana:

STVA = Structural Capital Value Added $=$ rasio dari SC terhadap VA.

$\mathrm{SC}=$ Structural Capital $=\mathbf{V A}-\mathbf{H C}$

$\mathrm{VA}=$ value added

3.3.1.5 Tahap Kelima: Menghitung Value Added Intellectual Coefficient (VAICTM).

VAICTM mengindikasikan kemampuan intelektual organisasi yang dapat juga dianggap sebagai BPI (Business Performance Indicator). VAICTM merupakan penjumlahan dari 3 komponen sebelumnya, yaitu:

VAIC $=$ VACA + VAHU + STVA

\subsubsection{Variabel Dependen}

Variabel dependen penelitian ini adalah profitabilitas. Variabel profitabilitas diproksikan dengan ROA (Chen et al., 2005) dalam Ulum (2007). ROA lebih dipilih daripada ROE karena total ekuitas yang merupakan denominator ROE adalah salah satu komponen dari VACA. Jika menggunakan ROE, maka akan terjadi double counting atas akun yang sama (yaitu ekuitas), dimana VACA (yang dibangun dari akun 'ekuitas') sebagai variabel independen dan ROE (yang juga dibangun dari akun 'ekuitas' dan laba bersih) menjadi variabel dependen.

Return On Assets (ROA).

ROA merefleksikan keuntungan bisnis dan efisiensi perusahaan dalam pemanfaatan total assets (Chen et al., 2005) dalam Ulum (2007). ROA dikalkulasi dengan formula:

$\mathrm{ROA}=$

\subsection{Metode Analisis}

\subsubsection{Model Regresi Data Panel}

Pengolahan data pada tesis ini untuk analisis (regresi) dan uji asumsi/uji hipotesis menggunakan Eviews 7.0. Sedangkan data yang digunakan dalam tesis ini adalah data panel, yaitu data yang mengkombinasikan time series dengan beberapa data cross section, dikarakteristikkan dengan adanya beberapa observasi (misalnya tahun) terhadap beberapa unit tetap (misalnya negara bagian atau perusahaan).

Dalam membuat regresi data panel, kita dapat menggabungkan tiga pendekatan yaitu pendekatan common effect, pendekatan fixed effect dan pendekatan random effect. 


\subsubsection{Pendekatan Common Effect (Pooled Least Square)}

Model Common Effect atau Pooled Least Square Model adalah model estimasi yang menggabungkan data time series dan data cross section dengan menggunakan pendekatan OLS (Ordinary Least Square) untuk mengestimasi parameternya. Dalam pendekatan ini tidak memperhatikan dimensi individu maupun waktu sehingga perilaku data antar perusahaan diasumsikan sama dalam berbagai kurun waktu. Pada dasarnya Model Common Effect sama seperti OLS dengan meminimumkan jumlah kuadrat, tetapi data yang digunakan bukan data time series atau data cross section saja melainkan data panel yang diterapkan dalam bentuk pooled. Bentuk untuk model Ordinary Least Square adalah:

Yit $=\beta 0+\beta$ Xit + Eit

Dimana:

Yit $=$ Variabel dependen pada unit observasi ke $-\mathrm{i}$ dan waktu ke $-\mathrm{t}$.

$\mathrm{Xit}=$ Variabel independen pada unit observasi ke $-\mathrm{i}$ dan waktu ke $-\mathrm{t}$

$\beta=$ Koefisien slope atau koefisien arah

$\beta 0=$ Intersep model regresi

Eit $=$ komponen error pada unit observasi ke $-\mathrm{i}$ dan waktu $\mathrm{ke}-\mathrm{t}$

\subsubsection{Pendekatan Fixed Effect}

Kondisi tiap objek saling berbeda. Bahkan satu objek pada satu waktu akan sangat berbeda dengan kondisi objek tersebut pada waktu yang lain. Oleh karena itu diperlukan suatu model yang dapat menunjukkan perbedaan konstanta antar objek, meskipun dengan koefisien regresor yang sama. Model ini dikenal dengan model regresi fixed effect (efek tetap). Efek tetap ini maksudnya adalah bahwa satu objek, memiliki konstanta yang tetap besarnya untuk berbagai periode waktu. Demikian juga dengan koefisien regresinya tetap besarnya dari waktu ke waktu (time variant), (Wing Wahyu Winarno , 2011 : 9.15). Untuk membedakan satu objek dengan objek lainnya, digunakan variabel semu (dummy). Oleh karena itu, model ini sering juga disebut dengan Least Square Dummy Variables (LSDV). Persamaan model ini adalah sebagi beikut :

Yit $=\beta 0 \mathrm{i}+\beta 1 \mathrm{Xit}+\beta 2 \mathrm{Xit}+\beta 3 \mathrm{~d} 1 \mathrm{i}+$ Eit

Dimana :

Yit $=$ Variabel dependen pada unit observasi ke-i dan waktu ke-t

Xit $=$ Variabel independen pada unit observasi ke-i dan waktu ke-t

$\beta=$ Koefisien slope atau koefisien arah

$\beta 0 \mathrm{i}=$ Intersep model regresi pada unit observasi ke- $\mathrm{i}$

$\varepsilon i t=$ komponen error pada unit observasi ke-i dan waktu ke- $t$

Perhatikan bahwa konstanta $\beta 0 \mathrm{i}$ sekarang diberi subscript $0 \mathrm{i}$, i menunjukkan objeknya. Dengan masing-masing objek memiliki konstanta yang berbeda. Variabel semu $\mathrm{d} 1 \mathrm{i}=1$ untuk objek pertama dan 0 untuk objek lainnya. Variabel semu $\mathrm{d} 2 \mathrm{i}=1$ untuk objek kedua dan 0 untuk objek lainnya (Wing: Wahyu Winarno, 2011, 9.15).

\subsubsection{Pendekatan Random Effect}

Random Effect (efek random) digunakan untuk mengatasi kelemahan metode efek tetap yang menggunakan variabel semu, sehingga model mengalami 
ketidakpastian. Tanpa menggunakan variabel semu, metode efek random menggunakan residual, yang diduga memiliki hubungan antar waktu dan antar objek. Tidak seperti pada model efek tetap ( $\beta 0$ dianggap tetap), pada model ini $\beta 0$ diasumsikan bersifat random, sehingga dapat dituliskan dalam persamaan :

$\beta 0=\beta 0+u i, i=1, \ldots, n$

sehingga persamaan model yang digunakan adalah :

Yit $=\beta 0 \mathrm{i}+\beta 1 \mathrm{Xit}+\beta 2 \mathrm{Xit}+\mathrm{ui}+$ Eit

Yit $=$ Variabel dependen pada unit observasi ke-i dan waktu ke-t

$\mathrm{Xit}=$ Variabel independen pada unit observasi ke-i dan waktu ke-t

$\beta 0 \mathrm{i}=$ Intersep model regresi pada unit observasi ke-i

ui $=$ komponen error pada unit observasi ke-i

$\varepsilon i t=$ komponen error pada unit observasi ke-i dan waktu ke-t

Namun untuk menganalisis dengan metode efek random ini ada satu syarat, yaitu objek data silang harus lebih besar daripada banyaknya koefisien.

\subsubsection{Pengujian Model Regresi}

Dalam menentukan model regresi data panel yang tepat untuk digunakan dalam analisis regresi data panel, maka kita dapat melakukan 2 pengujian model, yaitu :

\subsubsection{Uji Chow}

Uji Chow (F statistik) adalah pengujian yang dilakukan untuk mengetahui apakah model yang digunakan adalah common effect atau fixed effect. Rumus yang digunakan dalam test ini adalah :

$$
\text { Chow }=\frac{\mathrm{N}-1}{\mathrm{NT}-\mathrm{N}-\mathrm{K}}
$$

Dimana :

$\mathrm{N}=$ Jumlah data cross section

$\mathrm{T}=$ Jumlah data time series

$\mathrm{K}=$ Jumlah variabel penjelas

Pengujian Uji Chow dilakukan dengan hipotesis sebagai berikut :

H0 : Model menggunakan pendekatan common effect

$\mathrm{H} 1$ : Model menggunakan pendekatan fixed effect

Pengujian ini mengikuti distribusi F Statistik, dimana jika F statistik lebih besar dari F tabel maka H0 ditolak. Nilai Chow menunjukkan nilai F statistik dimana bila nilai Chow yang kita dapat lebih besar dari nilai $\mathrm{F}$ tabel yang digunakan berarti kita menggunakan model fixed effect. Atau kita dapat melihat kepada nilai probabilitas cross section $F$ dan Chi Square, dengan ketentuan:

- Jika probabilitas < 0,05, berarti H0 ditolak dan menggunakan H1 yaitu model fixed effect

- Jika probabilitas > 0,05, berarati H0 diterima dan H1 ditolak, maka menggunakan common effect

\subsubsection{Uji Hausman}

Uji Hausman digunakan untuk menentukan apakah menggunakan model fixed effect atau model random effect yang paling tepat. 
Uji Hausman dilakukan dengan hipotesis berikut :

$\mathrm{H} 0=$ Random Effect Model

$\mathrm{H} 1=$ Fixed Effect Model

Statistik Uji Hausman ini mengikuti distribusi statistik Chi Square dengan degree of freedom sebanyak $\mathrm{k}$, dimana $\mathrm{k}$ adalah jumlah variabel independen. Jika nilai statistik Hausman lebih besar dari nilai kritisnya maka $\mathrm{H} 0$ ditolak dan model yang tepat adalah model fixed effect, sedangkan sebaliknya bila nilai statistik hausman lebih kecil dari nilai kiritisnya maka model yang tepat adalah model random effect. Atau dapat melihat pada nilai probabilitas cross section random, dengan ketentuan sebagai berikut:

- Jika probabilitas < 0,05, berarti H0 ditolak dan menggunakan H1 yaitu model Fixed Effect

- Jika probabilitas > 0,05, berarati H0 diterima dan menolak H1 dan menggunakan $\mathrm{H} 0$ yaitu model Random Effect

Pemilihan Model Effect Tetap atau Model Effect Random juga dapat dilakukan dengan pertimbangan tujuan analisis atau kemungkinan data yang digunakan sebagai dasar pembuatan model, hanya dapat diolah oleh salah satu metode saja akibat berbagai persoalan teknis matematis yang melandasi perhitungan. Menurut Nachrowi (2006: 318) :

Jalan tengah dikemukakan pula oleh beberapa ahli Ekonometrika yang telah membuktikan secara matematis, dikatakan bahwa:

a) Jika data panel yang dimiliki mempunyai jumlah waktu lebih besar dibanding jumlah individu maka disarankan untuk menggunakan Metode Efek Tetap.

b) Jika data panel yang dimiliki mempunyai jumlah waktu lebih kecil dibanding jumlah indivisu maka disarankan menggunakan Metode Efek Random.

\subsubsection{Statistik Deskriptif}

Analisis statistik deskriptif merupakan teknik deskriptif yang memberikan informasi mengenai data yang dimiliki dan tidak bermaksud menguji hipotesis. Analis ini hanya digunakan untuk menyajikan dan menganalisis data disertai dengan perhitungan agar dapat memperjelas keadaan karakteristik data yang bersangkutan. Pengukuran yang digunakan dalam statistik deskriptif ini meliputi jumlah sampel, nilai minimum, nilai maksimum, nilai rata-rata (mean), dan standar deviasi.

Minimum digunakan untuk mengetahui jumlah terkecil data yang bersangkutan. Maksimum digunakan untuk mengetahui jumlah terbesar data yang bersangkutan. Mean digunakan untuk mengetahui rata-rata data yang bersangkutan. Standar deviasi digunakan untuk mengetahui seberapa besar data yang bersangkutan bervariasi dari rata-rata.

\subsubsection{Uji Asumsi Klasik}

\subsubsection{Uji Heteroskedastisitas}

Adalah terjadinya varians yang berbeda untuk variabel independen yang berbeda. Uji ini bertujuan untuk menguji apakah dalam model regresi terjadi ketidaksamaan varians dari residual satu pengamatan ke pengamatan lain. Model 
yang baik adalah terjadi homoskedastisitas atau tidak terjadi heteroskedastisitas. Banyak metode statistik yang dapat digunakan untuk menentukan apakah suatu model terbebas dari masalah heteroskedastisitas atau tidak. Untuk mengetahui adanya heterokedastisitas diantaranya adalah dengan melihat ada tidaknya pola tertentu dalam grafik scatter plot. Yang mendasari dalam pengambilan keputusan ini adalah (Wing Wahyu Winarno, 5.12):

a) Jika ada pola tertentu, seperti titik-titik yang ada membentuk pola tertentu yang teratur (bergelombang, melebar kemudian menyempit) maka tidak terjadi heteroskedastisitas.

b) Jika tidak ada pola yang jelas, serta titik-titik yang menyebar secara acak, maka diduga terjadi heteroskedastisitas.

\subsubsection{Uji Multikolinearitas}

Uji multikolinearitas bertujuan untuk menguji apakah adanya korelasi antar variabel bebas (independen) dalam model regresi. Multikolinearitas terjadi apabila antara variabel-variabel independen terdapat hubungan yang signifikan. Model regresi yang baik seharusnya bebas dari multikolinearitas. Untuk mendeteksi adanya masalah multikolinearitas adalah dengan memperhatikan besaran korelasi antar variabel independen. Pedoman suatu model regresi bebas multikolinearitas memilkiki kriteria sebagai berikut :

a) Koefisien korelasi antara variabel-variabel independen harus lemah, tidak lebih dari $90 \%$ atau dibawah 0,90 .

b) Jika korelasi kuat antara variabel-variabel independen dengan variabel independen lainnya (umumnya di atas 0,90 ), maka hal ini merupakan indikasi adanya multikolinearitas.

Uji Multikolinearitas diantaranya dapat dilakukan melalui correlation matrix dan melihat nilai VIF (Variance Inflation Factor). Tidak terjadi multikolinearitas jika nilai tolerance lebih besar dari 0,1 dan nilai VIF lebih kecil dari 10.

\subsubsection{Uji Autokorelasi}

Uji autokorelasi bertujuan untuk menguji apakah di dalam sebuah model regresi linear ada korelasi antara kesalahan pengganggu pada peridoe $t$ dengan periode t-1 (sebelumnya), autokorelasi ini timbul pada data yang bersifat time series. Uji autokorelasi ini dilakukan dengan membandingkan nilai Durbin Watson.

Nilai Durbin Watson akan berada di kisaran 0 hingga 4, seperti tampak pada tampilan berikut:

Tabel 3.5.

Tabel Nilai Durbin Watson

\begin{tabular}{|c|c|c|c|c|}
\hline $\begin{array}{c}\text { Tolak H0, } \\
\text { Berarti ada } \\
\text { otokorelasi } \\
\text { positif }\end{array}$ & $\begin{array}{c}\text { Tidak } \\
\text { dapat } \\
\text { diputuskan }\end{array}$ & $\begin{array}{c}\text { Tidak menolak } \\
\text { H0, } \\
\text { Berarti tidak } \\
\text { ada otokorelasi }\end{array}$ & $\begin{array}{c}\text { Tidak } \\
\text { dapat } \\
\text { diputuskan }\end{array}$ & $\begin{array}{c}\text { Tolak H0, } \\
\text { Berarti ada } \\
\text { otokorelasi } \\
\text { negatif }\end{array}$ \\
\hline 0 & & 2 & $4-d u$ & $4-\mathrm{dl}$ \\
\hline
\end{tabular}




$$
1,10 \quad 2,46 \quad 2,90
$$

Apabila nilai Durbin Watson di antara 1,54 dan 2,46, maka tidak ada otokorelasi (Wing Wahyu Winarno, 5.31).

\subsubsection{Uji Normalitas}

Uji normalitas bertujuan apakah dalam model regresi, dependen variabel dan independen variabel keduanya mempunyai distribusi normal atau tidak. Model regresi yang baik adalah memiliki distribusi normal atau mendekati normal. Salah satu cara termudah untuk melihat normalitas residual adalah dengan melihat grafik histogram yang membandingkan antara data observasi dengan distribusi yang mendekati normal.

Untuk menguji apakah distribusi data normal atau tidak, dengan menggunakan Eviews 7.0, dapat dilihat melalui histogram normaly test. Dengan ketentuan:

a) H0 pada data berdistribusi normal jika nilai Jarque-Bera tidak signifikan (lebih kecil dari 2), maka data berdistribusi normal.

b) Bila probabilitas lebih besar dari 5\%, maka data berdistribusi normal. (Wing Wahyu Winarno, 2011:5.43).

\subsubsection{Uji Hipotesis}

Untuk melakukan pengujian terhadap hipotesis-hipotesis yang diajukan, perlu digunakan analisa regresi melalui uji t maupun uji f. Tujuan digunakan analisa regresi adalah untuk mengetahui pengaruh variabel-variabel independen, terhadap variabel dependen, baik secara parsial maupun simultan, serta mengetahui besarnya dominasi variabel-variabel independen, terhadap variabel dependen. Metode pengujian terhadap hipotesa yang diajukan dilakukan dengan pengujian secara parsial dan secara simultan. Langkah-langkah untuk menguji hipotesis-hipotesis yang diajukan didalam penelitian ini adalah :

\subsubsection{Uji statistik $t$}

Uji statistik t digunakan untuk menunjukkan seberapa jauh pengaruh satu variabel penjelas/independen secara parsial dalam menerangkan variasi variabel independen. Hipotesis yang digunakan adalah :

a) $\mathrm{H} 0$ = secara parsial tidak ada pengaruh signifikan dari variabel independen terhadap variabel dependen.

b) $\mathrm{H1}=$ secara parsial ada pengaruh signifikan dari variabel independen terhadap variable dependen.

Kriteria pengambilan keputusan adalah sebagai berikut :

1) Berdasarkan perbandingan $\mathrm{t}$-statistik dengan $\mathrm{t}$-tabel Untuk menentukan nilai statistik t-tabel ditentukan tingkat signifikansi 5\% dengan derajat kebebasan $\mathrm{df}=(\mathrm{n}-\mathrm{k})$, dimana $\mathrm{n}$ adalah jumlah observasi dan $\mathrm{k}$ adalah banyaknya perkiraan yang harus dibuat atau banyaknya variabel yang tercakup, dengan kriteria uji adalah :

- Jika t-hitung > t-tabel $(\alpha / 2, \mathrm{n}-\mathrm{k})$, maka H0 ditolak dan $\mathrm{H} 1$ diterima

- Jika t-hitung < t-tabel $(\alpha / 2, \mathrm{n}-\mathrm{k})$, maka H0 diterima maka H1 ditolak 
2) Berdasarkan probabilitas

- Jika probabilitas ( $\mathrm{p}$-value $) \geq 0.05$, maka $\mathrm{H} 0$ diterima dan $\mathrm{H} 1$ ditolak

- Jika probabilitas (p-value $\leq 0.05$, maka H0 ditolak dan H1 diterima

\subsubsection{Uji Statistik F}

Uji statistik $\mathrm{F}$ digunakan untuk menguji pengaruh dari seluruh variabel bebas secara bersama-sama terhadap variabel terikat. Hipotesis untuk uji F yaitu :

- $\mathrm{HO}=$ secara bersama-sama tidak ada pengaruh signifikan dari variabel independen terhadap variabel dependen.

- $\quad$ H1 = secara bersama-sama ada pengaruh signifikan dari variabel independen terhadap variabel dependen.

Nilai statistik F dapat ditentukan dengan kriteria penerimaan hipotesis sebagai berikut :

\section{1) Berdasarkan perbandingan F-statistik/F-hitung dengan F-tabel.}

Untuk menentukan nilai $\mathrm{F}$ tabel dengan tingkat signifikansi sebesar 5\%, dengan derajat kebebasan (degree of freedom) df $=(\mathrm{k}-1)$ dan $(\mathrm{n}-\mathrm{k})$, diamana $\mathrm{n}$ adalah jumlah observasi, $\mathrm{k}$ adalah jumlah variabel, dengan kriteria uji yang digunakan adalah :

- Jika F-hitung > F-tabel $(\mathrm{k}-1 ; \mathrm{n}-\mathrm{k})$, maka H0 ditolak H1 diterima

- Jika F-hitung < F-tabel (k - 1; n - k), maka H0 diterima H1 ditolak

\section{2) Berdasarkan probabilitas}

- Jika probabilitas ( $\mathrm{p}$-value $) \geq 0.05$, maka H0 diterima dan $\mathrm{H} 1$ ditolak

- Jika probabilitas ( $\mathrm{p}$-value $) \leq 0.05$, maka H0 ditolak dan H1 diterima

\section{3) Koefisien Determinasi $\left(\mathbf{R}^{2}\right)$}

Koefisien determinasi digunakan untuk melihat kontribusi kemampuan menjelaskan dari variabel independen secara bersama-sama terhadap variabel terikat, dimana nilai koefisiennya terletak antara $0 \leq \mathrm{x} \leq 1$, apabila $\mathrm{R}^{2}=0$ berarti tidak ada hubungan antara variabel independen dengan variabel dependen, sedangkan $\mathrm{R}^{2}=1$ berarti adanya suatu hubungan yang sempurna. Nilai Adjusted $R$ square adalah suatu indikator yang digunakan untuk mengetahui pengaruh penambahan suatu variable indenpenden ke dalam suatu persamaan regresi. Nilai adjusted $R^{2}$ telah dibebaskan dari pengaruh derajat kebebasan (degree of freedom).

\section{HASIL DAN PEMBAHASAN}

\subsection{Statistik Deskriptif}

Intellectual Capital yang diukur dengan Value Added Intellectual Coeffcient (VAIC ${ }^{\mathrm{TM}}$ ) dengan elemen Capital Employed (Modal Pelayanan), Human Capital (Modal Manusia) dan Structural Capital (Modal Struktural) serta kinerja perusahaan yang diwakili oleh variabel indikator Return On Asset (ROA) pada perusahaan sektor properti dan real estate yang tercatat di Bursa Efek Indonesia selama periode penelitian tahun 2011 - 2015 menunjukkan tren 
menurun pada tahun 2015.

Return On Asset (ROA) tertinggi selama periode 2011-2015 dicapai oleh Modernland Realty Ltd. Tbk (MDLN) yaitu sebesar 25,41\% di tahun 2013, sedangkan terendah dicapai oleh Megapolitan Development Tbk (EMDE) yaitu sebesar 0,22\%. Rata-rata Return On Asset (ROA) sektor properti dan real estate pada periode ini adalah 6,52\%. Return On Asset (ROA) sektor properti dan real estate pada periode 2011 - 2015, tidak ada yang menunjukkan trend yang selalu meningkat.

Elemen Modal Pelayanan (Capital Employed-VACA) yang tertinggi terjadi pada tahun 2014 yaitu sebesar 63\% yang dicapai oleh PP (Persero) Tbk (PTPP), sedangkan yang terendah adalah sebesar $1,57 \%$ yang diraih oleh Pikko Land Development Tbk. (RODA) tahun 2011. Rata-rata nilai Elemen Modal Pelayanan (Customer Capital-VACA) dari semua perusahaan sektor properti dan real estate pada periode 2011-2015 ini adalah sebesar 21,58\%.

Elemen Modal Manusia (Human capital-VAHU) sektor properti dan real estate pada periode 2011-2015 yang tertinggi adalah sebesar $1.282 \%$ yang diraih oleh Roda Vivatex Tbk (RDTX) pada tahun 2015, sedangkan yang terendah adalah sebesar 100,69\% yang diraih oleh Indonesia Prima Property Tbk (OMRE) pada tahun 2015, dengan rata-rata $V A H U$ selama periode ini dari semua sektor properti dan real estate adalah 461,8\%. Sedangkan sektor properti dan real estate yang Elemen Modal Manusia (Human capital-VAHU)nya selalu berada diatas rata-rata adalah Lippo Cikarang Tbk (LPCK) dan Pakuwon Jati Tbk (PWON).

Elemen Modal Struktural (Structural Capital-STVA) sektor properti dan real estate pada periode 2011 - 2015 yang tertinggi terjadi pada tahun 2013 yaitu sebesar 98,03\% yang dicapai oleh PP (Persero) Tbk (PTPP). Sedangkan elemen Modal Struktural (Structural Capital-STVA) terendah sebesar 0,68\% pada tahun 2015 yang terjadi pada Indonesia Prima Property Tbk (OMRE). Rata-rata nilai dari Elemen Modal Struktural (Structural Capital-STVA) sektor properti dan real estate pada periode 2011-2015 adalah sebesar 71,1\%.

Elemen Intelectual Capital (VAIC) yang tertinggi pada tahun 2012 sebesar $1.393 \%$ diraih oleh Jaya real Property Tbk (JRPT). Sedangkan elemen Intelectual Capital (VAIC) yang terendah terjadi tahun 2015 oleh Indonesia Prima Property Tbk (OMRE) sebesar 559,86\%. Rata-rata besarnya Intelectual Capital (VAIC) pada periode 2011 - 2015 sebesar 559,9\%.

\subsection{Uji Model}

Tabel 4.1. Uji Chow

Equation: Untitled

Redundant Fixed Effects Tests

Test cross-section fixed effects

\begin{tabular}{lrrr}
\hline \hline Effects Test & Statistic & d.f. & Prob. \\
\hline \hline Cross-section F & 6.420141 & $(36,144)$ & 0.0000 \\
Cross-section Chi-square & 177.127555 & 36 & 0.0000 \\
\hline \hline
\end{tabular}

Sumber: Output Eviews 
Uji Chow menunjukkan bahwa nilai probabilitas cross section $F$ adalah 0.0000 atau $<0.05$, maka H0 ditolak dan menerima H1, berarti menggunakan pendekatan fixed effect.

Tabel 4.2

Uji Hausman

Correlated Random Effects - Hausman Test

Equation: Untitled

Test cross-section random effects

\begin{tabular}{lccc}
\hline \hline Test Summary & i-Sq. Statistic & Chi-Sq. d.f. & Prob. \\
\hline \hline Cross-section random & 2.063386 & 4 & 0.7241 \\
\hline \hline \hline
\end{tabular}

Sumber: Output Eviews

Uji hausman menunjukkan bahwa nilai probabilitas cross section random adalah 0,7241 atau > 0,05, maka menerima $\mathrm{H} 0$, berarti model penelitian menggunakan pendekatan Random Effect.

Dari hasil kedua uji model yang digunakan yaitu antara uji chow dan uji hausman menunjukkan hasil yang tidak konsisten. Uji chow menunjukkan jika model terpilih adalah Model Fixed Effect, sedangkan uji hausman menunjukkan hasil Model Random Effect. Sehingga dengan melihat data panel penelitian ini memiliki jumlah waktu (t) sebanyak 5 tahun dan jumlah individu (n) sebanyak 37, $\mathrm{t}<\mathrm{n}$, maka disimpulkan dalam penelitian ini menggunakan Model Random Effect.

Menurut Gujarati \& Porter (2009), persamaan yang memenuhi asumsi klasik hanya persamaan yang menggunakan metode Generalized Least Square (GLS). Dalam eviews model estimasi yang menggunakan metode GLS hanya random effect model, sedangkan fixed effect dan common effect menggunakan Ordinary Least Square (OLS). Dengan demikian perlu atau tidaknya pengujian asumsi klasik dalam penelitian ini tergantung pada hasil pemilihan metode estimasi. Apabila berdasarkan pemilihan metode estimasi yang sesuai untuk persamaan regresi adalah random effect, maka tidak perlu dilakukan uji asumsi klasik.

Dalam penelitian ini digunakan Model Random Effect, sehingga tidak dilakukan uji asumsi klasik.

\subsection{Hasil Uji Regresi}

Hasil regresi diperoleh persamaan regresi linear berganda sebagai berikut: $\mathrm{ROA}=0.026148+0.015856 \mathrm{VACA}+0.015798 \mathrm{VAHU}+0.060118 \mathrm{STVA}+$ $0.027028 \mathrm{VAIC}+\varepsilon i t$

Tabel 4.3

Model Random Effect

Dependent Variable: ROA

Method: Panel EGLS (Cross-section random effects) 
Date: 08/12/17 Time: 11:27

Sample: 20112015

Periods included: 5

Cross-sections included: 37

Total panel (balanced) observations: 185

Swamy and Arora estimator of component variances

\begin{tabular}{|c|c|c|c|c|}
\hline Variable & Coefficient & Std. Error & t-Statistic & Prob. \\
\hline VACA & 0.015856 & 0.025952 & 0.610972 & 0.5420 \\
\hline VAHU & 0.015798 & 0.002967 & 5.324171 & 0.0000 \\
\hline STVA & 0.060118 & 0.023490 & 2.559279 & 0.0113 \\
\hline VAIC & 0.027028 & 0.002831 & 9.546109 & 0.0000 \\
\hline $\mathrm{C}$ & 0.026148 & 0.012387 & 2.110960 & 0.0362 \\
\hline & \multicolumn{2}{|c|}{ Effects Specification } & S.D. & Rho \\
\hline \multicolumn{3}{|c|}{ Cross-section random } & 0.026951 & 0.5470 \\
\hline \multicolumn{3}{|c|}{ Idiosyncratic random } & 0.024526 & 0.4530 \\
\hline
\end{tabular}

Weighted Statistics

\begin{tabular}{lll}
\hline \hline R-squared & 0.5678521ean dependent var & 0.024578 \\
Adjusted R-squared & $\mathbf{0 . 5 5 8 2 4 9}$.D. dependent var & 0.036702 \\
S.E. of regression & 0.024394um squared resid & 0.107112 \\
F-statistic & $\mathbf{5 9 . 1 3 1 0 4}$ ) urbin-Watson stat & $\mathbf{1 . 7 0 2 7 8 8}$ \\
Prob(F-statistic) & $\mathbf{0 . 0 0 0 0 0 0}$ & \\
\hline \hline
\end{tabular}

Sumber: Output Eviews

\subsection{Hasil Uji Secara Parsial dan Simultan}

Hasil pengujian dengan analisa regresi data panel model random effect menunjukkan hasil t-hitung untuk variabel independen Value Added Capital Employed (VACA) adalah sebesar 0.610972, sementara nilai t- tabel dengan derajat kebebasan/degree of freedom $(\mathrm{df})=5 \%$, $\mathrm{df}=\mathrm{n}-\mathrm{k}=185-5=180$, diperoleh nilai t-tabel adalah 1.97323. Sehingga t-hitung > t-tabel yaitu 0.610972 $<1.97323$, kemudian terlihat dari nilai probabilitas yaitu sebesar 0.5420 yang lebih besar dari 0.05 hal ini menunjukkan $\mathrm{H}_{1}$ ditolak dan $\mathrm{H}_{0}$ diterima (dimana $\mathrm{H}_{1}$ menunjukkan ada pengaruh yang signifikan secara parsial dan $\mathrm{H}_{0}$ tidak ada pengaruh secara parsial).

Hasil pengujian dengan analisa regresi data panel model random effect menunjukkan hasil t-hitung untuk variabel independen Value Added Human Capital (VAHU) adalah sebesar 5.324171, sementara nilai t- tabel dengan derajat kebebasan/degree of freedom $(\mathrm{df})=5 \%$, $\mathrm{df}=\mathrm{n}-\mathrm{k}=185-5=180$, diperoleh nilai t-tabel adalah 1.97323. Sehingga t-hitung $>$ t-tabel yaitu 5.324171 > 1.97323, kemudian terlihat dari nilai probabilitas yaitu sebesar 0.0000 yang lebih kecil dari 0.05 hal ini menunjukkan $\mathrm{H}_{1}$ diterima dan $\mathrm{H}_{0}$ ditolak (dimana $\mathrm{H}_{1}$ menunjukkan 
ada pengaruh yang signifikan secara parsial dan $\mathrm{H}_{0}$ tidak ada pengaruh secara parsial).

Hasil pengujian dengan analisa regresi data panel model random effect menunjukkan hasil t-hitung untuk variabel independen Structural Capital Value Added (STVA) adalah sebesar 2.559279, sementara nilai t-tabel dengan derajat kebebasan/degree of freedom $(\mathrm{df})=5 \%, \mathrm{df}=\mathrm{n}-\mathrm{k}=185-5=180$, diperoleh nilai t-tabel adalah 1.97323. Sehingga t-hitung > t-tabel yaitu $2.559279>$ 1,97253 , kemudian terlihat dari nilai probabilitas yaitu sebesar 0.0113 yang lebih kecil dari 0.05 hal ini menunjukkan $\mathrm{H}_{1}$ diterima dan $\mathrm{H}_{0}$ ditolak (dimana $\mathrm{H}_{1}$ menunjukkan ada pengaruh yang signifikan secara parsial dan $\mathrm{H}_{0}$ tidak ada pengaruh secara parsial).

Hasil pengujian dengan analisa regresi data panel model random effect menunjukkan hasil t-hitung untuk variabel independen Value Added Coeffisien Intelectual (VAIC) adalah sebesar 9.546109, sementara nilai t-tabel dengan derajat kebebasan/degree of freedom $(\mathrm{df})=5 \%$, $\mathrm{df}=\mathrm{n}-\mathrm{k}=185-5=180$, diperoleh nilai t-tabel adalah 1.97323. Sehingga t-hitung $>$ t-tabel yaitu 9.546109 $>1,97253$, kemudian terlihat dari nilai probabilitas yaitu sebesar 0,0000 yang lebih kecil dari 0.05 hal ini menunjukkan $\mathrm{H}_{1}$ diterima dan $\mathrm{H}_{0}$ ditolak (dimana $\mathrm{H}_{1}$ menunjukkan ada pengaruh yang signifikan secara parsial dan $\mathrm{H}_{0}$ tidak ada pengaruh secara parsial).

Berdasarkan hasil output Eviews model random effect yang, nilai F-hitung yaitu sebesar 59.13104 sementara $\mathrm{F}$ - tabel dengan tingkat signifikansi 5\% dan df1 $(\mathrm{k}-1)=5-1=4$ dan df2 $(\mathrm{n}-\mathrm{k})=185-5=180$, didapat F-tabel sebesar 2.42 . Dengan demikian F-hitung > F-tabel $(59.13104>2.42)$ kemudian juga terlihat dari nilai probabilitas (prob) dari model diatas yaitu sebesar 0,000000 yang lebih kecil dari tingkat signifikansi 0.05 , sehingga $\mathrm{H} 0$ ditolak. Hal ini berarti bahwa variabel Value Added Capital Employed (VACA), Value Added Human Capital (VAHU), Structural Capital Value Added (STVA), dan Value Added Intellectual Coeffisien (VAIC) secara bersama-sama (simultan) mempunyai pengaruh yang signifikan terhadap Return On Aset (ROA), sehingga model regresi dapat digunakan untuk memprediksi variabel dependen.

Besarnya angka Adjusted $R$-Squared ( $\mathrm{R}^{2}$ ) adalah 0.558249. Hal ini menunjukkan bahwa persentase sumbangan pengaruh variabel independen terhadap variabel dependen adalah sebesar 55,8\%. Atau dapat diartikan bahwa variabel independent yang digunakan dalam model mampu menjelaskan sebesar $55,8 \%$ terhadap variabel dependennya. Sedangkan sisanya 44,2\% lainnya dipengaruhi faktor lain di luar model regresi tersebut.

Menurut interval koefisien determinasi, nilai koefisien determinasi sebesar 0.558249 berada pada interval 0,40 - 0,599 yang berarti tingkat hubungan antara Value Added Capital Employed (VACA), Value Added Human Capital (VAHU), Structural Capital Value Added (STVA), dan Value Added Intellectual Coeffisien (VAIC) yang mempengaruhi Return On Asset (ROA) berada pada tingkat sedang. 


\section{KESIMPULAN DAN SARAN}

\subsection{Kesimpulan}

Berdasarkan hasil pengujian dan pembahasan sebagaimana telah disajikan pada bagian sebelumnya, maka dapat ditarik beberapa kesimpulan :

1) Value Added Capital Employed (VACA) tidak berpengaruh terhadap profitabilitas yang diukur dengan Return On Asset (ROA) pada perusahaan industri jasa sektor properti dan real estate karena perusahaan sektor tersebut tidak mengandalkan modal berupa fisik saja tetapi menggunakan teknologi informasi dalam melakukan pelayanan terhadap pelanggan.

2) Value Added Human Capital (VAHU) berpengaruh signifikan terhadap profitabilitas yang diukur dengan Return On Asset (ROA) pada perusahaan industri jasa sektor properti dan real estate. Hal tersebut terlihat pada perusahaan sektor ini memiliki sumber daya manusia yang handal dan mampu bersaing sehingga meningkatkan profitabilitas.

3) Structural Capital Value Added (STVA) berpengaruh signifikan terhadap profitabilitas yang diukur dengan Return On Asset (ROA) pada perusahaan industri jasa sektor properti dan real estate. Hal tersebut ditunjukkan dengan adanya organisasional yang baik dan menunjukkan garis wewenang dan tanggungjawab.

4) Value Added Intellectual Capital (VAIC) berpengaruh signifikan terhadap profitabilitas yang diukur dengan Return On Asset (ROA) pada perusahaan industri jasa sektor properti dan real estate. Hal tersebut menunjukkan pada perusahaan sampel, intellectual capital memberikan kontribusi yang kuat pada teori stakeholder yang menekankan pada laba akuntansi dan keakuratan value added dalam menentukan return.

5) Intellectual Capital (IC) yang diukur dengan Value Added Capital Employed (VACA), Value Added Human Capital (VAHU), Structural Capital Value Added (STVA) dan Value Added Intellectual Capital (VAIC) secara simultan berpengaruh signifikan terhadap profitabilitas yang diukur dengan Return On Asset (ROA) pada perusahaan industri jasa sektor properti dan real estate, berdasarkan persamaan regresi data panel random effect model : ROA = $0.026148+0.015856 \mathrm{VACA}+0.015798 \mathrm{VAHU}+0.060118 \mathrm{STVA}+$ $0.027028 \mathrm{VAIC}+$ cit dengan angka Adjusted $R$-Squared $\left(\mathrm{R}^{2}\right)$ adalah 0.558249 . Hal ini menunjukkan bahwa persentase sumbangan pengaruh variabel independen Intellectual Capital terhadap variabel dependen Return On Asset (ROA) adalah sebesar 55,8\%, sedangkan sisanya 44,2\% dipengaruhi oleh variabel lain diluar model regresi penelitian ini.

\subsection{Saran}

Dengan hasil penelitian ini, penulis memberikan saran-saran berikut:

1) Perusahaan atau organisasi dapat mengelola modal intelektual yang dimiliki baik modal fisik, modal manusia, dan modal stuktural dengan lebih baik karena terbukti modal intelektual ini meningkatkan profitabilitas sehingga akan meningkatkan nilai tambah perusahaan untuk dapat menghasilkan keunggulan bersaing. 
2) Pemerintah diharapkan dapat membuat peraturan standar tentang pengungkapan dan pelaporan aset tidak berwujud dalam hal ini Intelectual Capital sehingga ada pengukuran dan pelaporan yang jelas terhadap modal intelektual tersebut.

\section{DAFTAR PUSTAKA}

Alviani Dan Purnamasari. (2011). Pengaruh Intellectual Capital Terhadap Kinerja Perusahaan: Perspektif Balanced Scorecard Jurnal Akuntansi Bisnis, Vol. IX No.18 Fakultas Ekonomi Unika Soegijapranata.

Bontis. (2004). National Intellectual Capital Indexa United Nations Initiative For Thearab Region Journal Of Intellectual Capital Vol. 5 No. 1.

Brigham, Eugene F. And Michael C. Enrhardt. (2010). Dasar-Dasar Manajemen Keuangan Essentials Of Financial Management, Buku I, Edisi 11, Penerbit Salemba Empat, Jakarta.

Gujarati dan Porter. (2009). Dasar-Dasar Ekonometrika. Jakarta : Salemba Empat

Hadiwijaya Dan Rohman.(2013). Pengaruh Intellectual Capital Terhadap Nilai Perusahaan Dengan Kinerja Keuangan Sebagai Variabel Intervening Diponegoro Journal Of Accounting Volume 2, Nomor 3, Halaman 1-7. Semarang.

Heryanto Dan Lukman. (200)8, Statistik Ekonomi. (Jakarta: Lembaga Penelitian Universitas Negeri Syarif Hidayatullah Jakarta.

Ikatan Akuntan Indonesia. (2002). Pernyataan Standar Akuntansi Keuangan No. 19. Salemba Empat. Jakarta

Imam Ghozali (2009). Aplikasi Analisis Multivariate Dengan Program Spss, (Semarang : Universitas Diponegoro, Edisi Keempat.

Irawan Dan Achmad. (2014). Analisis Pengaruh Ukuran Perusahaan Terhadap Kinerja Intellectual Capital Dengan Struktur Kepemilikan Sebagai Variabel Moderating Diponegoro Journal Of Accounting Volume 3, Nomor 2, Halaman 1-11 .Issn (Online): 2337-3806.

Kasmir. (2010). Pengantar Manajemen Keuangan, Edisi Pertama, Kencana Prenada

Lestari Dan Krisnawati. (2014). Analisis Pengaruh Intellectual Capital Terhadap Kinerja Keuangan Perusahaan Industri Jasa (Non-Keuangan) Yang Terdaftar Di Bursa Efek Indonesia Tahun 2010-2013. Jurnal Fakultas Ekonomi Dan Bisnis, Universitas Telkom.

Laporan Keuangan Tahunan, Akses Online Bursa Efek Indonesia www.idx.co.id Mehri Et All. (2013). Intellectual Capital And Firm Performance Of High Intangible Intensive Industries: Malaysia Evidence. Asian Social Science; Vol. 9, No. 9; 2013 Issn 1911-2017 E-Issn 1911-2025 Published By Canadian Center Of Science And Education.

Munawir. (2008). Analisis Laporan Keuangan, Edisi Keempat, Cetakan Ketiga Belas, Penerbit. Liberty, Yogyakarta. 
Muhammad Iqbal. (2016). Tahapan Analisis Regresi Data Panel, (online) Tersedia : https://dosen.perbanas.id/regresi-data-panel-3-penggunaan-eviews-8.

Nachrowi Djalal Nachrowi Dan Hardius Ustman. (2006). Pendekatan Populer dan Praktis Ekonometrika Untuk Analisis Ekonomi dan Keuangan, Lembaga Penerbit Fakultas Ekonomi Universitas Indonesia, Jakarta.

Pulic, A. (1998). Measuring the performance of intellectual potential in knowledge economy. available online at: www.vaic-on.net. (accessed January 2009).

Rusilowati Umi. (2013). Manajemen Pengetahuan Berbasis Teknologi Informasi Dalam Konteks Pembelajaran Organisasi, Asmoro Mediatama, Tangerang Selatan.

Salim Dan Karyawati. (2013) Pengaruh Modal Intelektual Terhadap Kinerja Keuangan. Journal Of Business And Entrepreneurship Issn: 2302 - 4119 Vol. 1, No. 2; Mei 2013. Sampoerna School Of Business

Shochrul R, Ajija, dkk. (2011). Cara cerdas menguasai EVIEWS. Jakarta : salemba empat

Sawarjuwono Dan Kadir, (2003). Intellectual Capital: Perlakuan, Pengukuran Dan Pelaporan (Sebuah Library Research) Jurnal Akuntansi \& Keuangan Vol. 5, No. 1, Mei 2003: 35 - 57 Jurusan Ekonomi Akuntansi, Fakultas Ekonomi - Universitas Kristen Petra.

Sugiyono. (2010). Metode Penelitian Kuantitatif Kualitatif $R \& D$, Penerbit Alfabeta.

Suhendah, Rousilita. (2012). Pengaruh Intellectual Capital Terhadap Profitabilitas, Produktivitas, Dan Penilaian Pasar Pada Perusahaan Yang Go Public Di Indonesia Pada Tahun 2005-2007. Jurnal Unversitas Tarumanegara.

Ulum, Ihyaul (2007). Pengaruh Intellectual Capital Terhadap Kinerja Keuangan Perusahaan Perbankan Di Indonesia. Tesis. Semarang:Universitas Diponegoro.

Ulum, Ihyaul. (2009). Intelectual Capital Konsep dan KaJIAn Empiris. Penerbit Graha Ilmu, Malang.

Widyaningdyah Dan Aryani. (2013). Intellectual Capital Dan Keunggulan Kompetitif (Studi Empiris Perusahaan Manufaktur Versi Jakarta Stock Industrial Classification-Jasica), Jurnal Akuntansi Dan Keuangan, Vol. 15, No. 1, Mei 2013, 1-14 Doi: 10.9744/Jak.15.1.1-14 .Issn 1411-0288 Print / Issn 2338-8137 Online

Wing Wahyu Winarno. (2011). Analisis Ekonometrika Dan Statistika Dengan Eviews, (Yogyakarta: Unit Penerbit Dan Percetakan Stim Ykpn.

Widarjono. Agus . (2007). Ekonometrika Teori dan Aplikasi untuk Ekonomi dan Bisnis. Ekonisia. Yogyakarta

Yuniasih Dkk. 2009, Pengaruh Modal Intelektual Pada Kinerja Pasar Perusahaan (Studi Empiris Pada Perusahaan Keuangan Yang Terdaftar Di Bursa Efek Indonesia) Jurnal Fakultas Ekonomi Universitas Udayana. 